\title{
REACTION OF MELON GENOTYPES TO THE ROOT'S ROT CAUSED BY Monosporascus ${ }^{1}$
}

\author{
RUI SALES JÚNIOR ${ }^{2 *}$, ROSEMBERG FERREIRA SENHOR ${ }^{3}$, SAMI JORGE MICHEREFF $^{4}$, ANDREIA MITSA $^{2}$ \\ PAIVA NEGREIROS ${ }^{2}$
}

\begin{abstract}
Monosporascus root rot and vine decline (MRRVD) is an important disease in the melon crop in Brazil. In our research, we evaluated the reaction of 45 melon genotypes to $M$. cannonballus in two successive cropping seasons in a greenhouse. Melon seedlings were transplanted into naturally infested soil. The evaluation of the genotypes was performed after 55 days, using a score scale to group each genotype into one of five classes and to calculate the disease severity index. None of the genotypes showed an immune reaction to $M$. cannonballus, regardless of the season. In the first cycle, only $28.9 \%$ ('AF 464', 'Auraprince', 'DRG 2278', 'Estoril', 'Guaporé', 'Kousto', 'Mabel', 'Magisto', 'Massai', 'Nectar', '8530', 'RZ 34130' and 'RZ 34292') had a similar reaction to the high resistance to the MRRVD. Most genotypes (66.7\%) behaved as moderately resistant while $4.4 \%$ were susceptible and none were highly susceptible. Conversely, in the second cycle, no genotype showed a reaction similar to high resistance while $42.2 \%$ behaved as moderately resistant, $48.9 \%$ as susceptible, and $8.9 \%$ as highly susceptible. The severity levels ranged from 7.5 to $60 \%$ and 27.5 to $92.5 \%$ for the first and second cycles, respectively. The genotypes 'DRG 2278', 'Estoril', 'Guaporé', 'Kousto', 'Mabel', 'Massaï', 'RZ 34130' and 'RZ 34292' were identified as highly resistant and moderately resistant in the first and second cycles of cultivation, respectively. Therefore, these genotypes are promising sources of resistance to $M$. cannonballus and should be preferred in commercial fields infested with the pathogen.
\end{abstract}

Keywords: Cucumis melo. Genetic resistance. Monosporascus root rot and vine decline. Root pathogen.

\section{REAÇÃO DE GENÓTIPOS DE MELOEIRO A PODRIDÃO DE RAÍZES CAUSADA POR Monosporascus}

\begin{abstract}
RESUMO - A Podridão de raízes por Monosporascus e declínio de ramas (PRMDR) é uma importante doença em meloeiro no Brasil. Nesta pesquisa, foi analisada a reação de 45 genótipos de meloeiro a M. cannonballus em dois ciclos de cultivo sucessivos em casa de vegetação. Mudas de meloeiro foram transplantadas em solo naturalmente infestado. A avaliação dos genótipos foi realizada após 55 dias, com o auxílio de escala de notas para agrupamento de cada genótipo em cinco classes e cálculo do índice de severidade da doença. Nenhum dos genótipos apresentou reação de imunidade a $M$. cannonballus. No primeiro ciclo de cultivo, somente $28,9 \%$ ('AF 464', 'Auraprince', 'DRG 2278', 'Estoril', 'Guaporé', 'Kousto', 'Mabel', 'Magisto', 'Massaï', 'Néctar', '8530', 'RZ 34130' e 'RZ 34292') apresentaram reação semelhante à alta resistência a PRMDR. A maioria dos genótipos $(66,7 \%)$ se comportou como medianamente resistente, enquanto 4,4\% como suscetível e nenhum como altamente suscetível. No segundo ciclo de cultivo, nenhum genótipo apresentou reação semelhante à alta resistência, enquanto $42,2 \%$ se comportaram como medianamente resistentes, $48,9 \%$ como suscetíveis e $8,9 \%$ como altamente suscetíveis. Os níveis de severidade variaram entre 7,5 a 60\% para o primeiro ciclo de cultivo e entre 27,5 a 92,5\% para o segundo ciclo. Os genótipos 'DRG 2278', 'Estoril', 'Guaporé', 'Kousto', 'Mabel', 'Massaï', 'RZ 34130' e 'RZ 34292' foram identificadas como altamente resistentes e medianamente resistentes, no primeiro e segundo ciclos de cultivo, respectivamente. Estes genótipos constituem fontes promissoras de resistência a $M$. cannonballus e devem ser preferidos em campos comerciais infestados pelo patógeno.
\end{abstract}

Palavras-chave: Cucumis melo. Resistência genética. Podridão de raízes por Monosporascus e declínio de ramas. Patógeno radicular.

\footnotetext{
${ }^{*}$ Corresponding author

${ }^{1}$ Received for publication in $05 / 02 / 2018$; accepted in $11 / 20 / 2018$.

Paper extracted from the doctoral thesis of the second author.

${ }^{2}$ Center for Agrarian Sciences, Universidade Federal Rural do Semi-Árido, Mossoró, RN, Brazil; jrrui@hotmail.com - ORCID: 0000-0001 -9097-0649, deia_mitsa@hotmail.com - ORCID: 0000-0002-9544-2527.

${ }^{3}$ Department of agronomy, Universidade Federal Rural de Pernambuco, Recife, PE, Brazil; berg_fit@hotmail.com - ORCID: 0000-00030208-3201.

${ }^{4}$ Center for Agrarian Sciences and Biodiversity, Universidade Federal do Cariri, Crato, CE, Brazil; sami.michereff@ufca.edu.br - ORCID: 0000-0002-2156-3502.
} 


\section{INTRODUCTION}

The north-eastern region is responsible for 95.7\% (570.8 t) of melon production (Cucumis melo L.) in Brazil, highlighting the supply of fruits to the domestic and export markets. The states of Rio Grande do Norte $(\mathrm{RN})$ and Ceará $(\mathrm{CE})$ are the largest producers in Brazil, accounting for $79.4 \%$ of C. melo production (IBGE, 2018).

The expansion of culture, allied with intensive and continuous cultivation without the adoption of integrated management practices, has contributed to increasing the incidence and severity of various diseases. Among them, the Monosporascus root rot and vine decline (MRRVD), caused by the fungus Monosporascus cannonballus Pollack \& Uecker, which is present in the main melon-producing areas in the states of $\mathrm{RN}$ and $\mathrm{CE}$ (ANDRADE et al., 2005; SALES JÚNIOR et al., 2010).

The MRRVD is one of the major diseases that has limited the production and expansion of melon and watermelon [Citrullus lanatus (Thunb.) Matsum. $\&$ Nakai] in the main producing regions of the world. Other cucurbits can also be attacked, including zucchini (Cucurbita pepo L.), pumpkin (C. moschata (Duchesne) Duchesne et Poir), winter squash ( $C$. maxima Duch.), sponge gourd (Luffa aegyptiaca Mill.), bottle gourd (Lagenaria siceraria (Molina) Standl.) and cucumber (Cucumis sativus L.) (COHEN et al., 2012). Currently, M. cannonballus is reported to cause MRRVD in 22 countries (COHEN et al., 2012; AL-MAWAALI et al., 2013; YAN et al., 2016; MARKAKIS et al., 2018).

The symptoms of MRRVD can be easily observed in adult melon plants at the time of harvest (MARTYN; MILLER, 1996; COHEN et al., 2012), wherein yellowing, wilting and dryness of basal leaves occur, followed by vine decline. In more extreme cases, it may cause the death of the plant. In roots, the presence of black spots (perithecia), associated with the reproductive structures of the fungus, may appear (MARTYN; MILLER, 1996).

Countless control strategies against this disease have been tested, either in isolation or in association with others, but, none of them showed efficiency. However, they can be effective when sustainable measures are incorporated (MEDEIROS et al., 2008), such as the use of green fertilisation (SALES JÚNIOR et al., 2017), post-harvest residue destruction (RADEWALD; FERRIN; STANGHELLINI, 2004), chemical control (PIVONIA et al., 2010), application of essential oils (FERNANDES et al., 2015; AWAD, 2016), use of plant-growth-promoting bacteria (ANTONELLI et al., 2013), use of biocontrol agents (ALEANDRI et al., 2015) and grafting on hybrid rootstocks of Cucurbita (AL-MAWAALI et al., 2016; EDELSTEIN et al., 2017).

The use of genetic control is an excellent alternative, however, so far, no source of resistance has been identified in commercial melon cultivars (FITA et al., 2009). In Spain, the authors Iglesias, Picó and Nuez (2000) recognised an accession from the $C$. melo ssp. agrestis 'Pat 81' group with resistance to MRRVD. This resistance source was crossed with a melon from the 'Piel de Sapo' group, from which new fruit quality strains with improved sugar content, yield and moderate resistance levels to MRRVD, were obtained (FITA et al., 2009).

The present study aimed to evaluate the reaction of 45 melon genotypes inoculated with $M$. cannonballus in two successive crop cycles, under greenhouse conditions.

\section{MATERIAL AND METHODS}

Two experiments were carried out in a greenhouse at the Universidade Federal Rural do Semi-Árido in Mossoró (RN, Brazil), in two successive crop cycles, with a minimum interval of 20 days between them. The first experiment consisted of the first crop cycle, which was carried out from November 2008 to January 2009; a hot and dry period, with temperature ranging from 24.5 to $42.6{ }^{\circ} \mathrm{C}$, and relative humidity between 50 and $74 \%$. The second crop cycle was carried out from February to April 2009; a humid period, with temperatures between 22.1 and $39.3{ }^{\circ} \mathrm{C}$, and relative humidity between 68 and $91 \%$. The city of Mossoró is situated at $5^{\circ} 11^{\prime} \mathrm{S}, 37^{\circ} 20^{\prime} \mathrm{W}$ of Greenwich, and $18 \mathrm{~m}$ above sea level. Based on Köppen's classification, the region's climate is characterised as BSh (warm semiarid) (ALVARES et al., 2014).

A collection of 45 commercial melon genotypes from different groups was evaluated in a naturally $M$. cannonballus-infested soil, including the commercial types Cantaloupe, Charantais, Galia, Harper, Honeydew, Piel de Sapo and Yellow (Table 1).

A sandy-loam soil was used $(\mathrm{pH}=7.2, \mathrm{~N}=$ 1.005 ppm, $\mathrm{P}=3 \mathrm{mg} \mathrm{dm}^{-3}, \mathrm{~K}=0.12 \mathrm{cmolc} \mathrm{dm}^{-3}, \mathrm{Al}$ $=1.35 \mathrm{cmolc} \mathrm{dm}^{-3}, \mathrm{Ca}+\mathrm{Mg}=0.85 \mathrm{cmolc} \mathrm{dm}^{-3}$ ), collected from a melon-producing area with a previous history of MRRVD occurrence, in the city of Icapuí (CE, Brazil). Before planting, 10 soil samples were collected, and the ascospore density of M. cannonballus was quantified by the commercial sugar flotation method, according to Sales Júnior et al. (2006). The mean densities of 3.6 and 1.0 ascospores $\mathrm{g}^{-1}$ of soil were detected at the beginning of the first and second cropping seasons, respectively.

Nine-day-old seedlings of the genotypes, grown in polystyrene trays of 200 cells filled with Plantmax $^{\circledR}$ substrate (Eucatex Mineral Ltda., Paulínia, Brazil), were transplanted into a 4-kgcapacity plastic vessel, filled with soil naturally infested with M. cannonballus. 
Before sowing, seeds were disinfested in $1.5 \% \mathrm{NaClO}$ solution for $2 \mathrm{~min}$, washed in running water, and left to dry for $45 \mathrm{~min}$ at room temperature $\left(25 \pm 2{ }^{\circ} \mathrm{C}\right)$ in an aseptic chamber. The control treatment consisted of melon seedlings in sterile soil (same soil, previously autoclaved). A randomised block experimental design was used, with four replications, wherein each replicate consisted of a four-plant pot.

In both cropping seasons, when melon plants reached 55 days after transplanting, roots were carefully extracted, washed in running water, and evaluated for severity of MRRVD, using the score scale adapted by Bruton et al. (2000), where $0=$ healthy with no lesion or discolouration, $1=$ slight discolouration, 2 = moderate discolouration and/or with lesions, $3=$ moderate discolouration and/or slight maceration, $4=$ severe discolouration and/or macerated root.

The average reaction for each genotype was calculated by the sum of notes of each plant divided by the total number of plants evaluated. This value was used to discriminate the genotypes into five reaction classes: $0=$ similar to immune; $0.1-1.0=$ highly resistant; $1.1-2.0=$ moderately resistant; $2.1-$
$3.0=$ susceptible; $3.1-4.0=$ highly susceptible. The final disease severity index (DSI) in each vessel was calculated according to McKinney (1923), by the following equation: DSI $=[\mathrm{S}$ (scale score $\times$ frequency) / (total number of units $\times$ maximum score) $] \times 100$, using the score scale data.

DSI data that did not meet the assumptions of variance analysis (normality of error distribution and homogeneity of variances), verified by the Lilliefors and Cochran tests, were transformed by $\sqrt{x+0.5}$ and submitted to analysis of variance. Means of the genotypes were compared by the Scott-Knott test ( $\mathrm{P}$ $\leq 0.05)$. All of the statistical analyses were performed using the SISVAR $^{\circledR} \quad 5.6$ statistical software (UFLA, Lavras, MG, Brazil).

\section{RESULTS AND DISCUSSION}

The melon cultivars studied, showed a wide variation of reaction to $M$. cannonballus in both successive cropping seasons. However, none of the 45 tested cultivars presented an immune reaction to the ascospore density of $M$. cannonballus present in the soil (Table 1).

Table 1. Reaction of melon genotypes to Monosporascus cannonballus in two crop cycles, under greenhouse conditions.

\begin{tabular}{|c|c|c|c|c|c|c|c|}
\hline \multirow[t]{3}{*}{ Genotypes } & \multirow{3}{*}{$\begin{array}{c}\text { Commercial } \\
\text { type }^{1}\end{array}$} & \multicolumn{3}{|c|}{ 1st Cycle (dry period) } & \multicolumn{3}{|c|}{ 2nd Cycle (wet period) } \\
\hline & & \multicolumn{2}{|c|}{ Class of disease } & \multirow{2}{*}{$\begin{array}{c}\text { Severity } \\
(\%)^{4}\end{array}$} & \multicolumn{2}{|c|}{ Class of disease } & \multirow{2}{*}{$\begin{array}{c}\text { Severity } \\
(\%)\end{array}$} \\
\hline & & Mean $^{2}$ & Reaction $^{3}$ & & Mean & Reaction & \\
\hline 'RZ 34292' & GA & 0.3 & HR & $7.5 \mathrm{c}$ & 1.6 & MR & $40.0 \mathrm{~b}$ \\
\hline 'RZ 34130’' & PS & 0.3 & HR & $7.5 \mathrm{c}$ & 2.0 & MR & $50.0 \mathrm{~b}$ \\
\hline ‘Massaï’ & $\mathrm{CH}$ & 0.5 & HR & $12.5 \mathrm{c}$ & 1.4 & MR & $35.0 \mathrm{~b}$ \\
\hline 'Estoril' & GA & 0.5 & HR & $12.5 \mathrm{c}$ & 1.7 & MR & $42.5 \mathrm{~b}$ \\
\hline 'Kousto' & $\mathrm{CA}$ & 0.6 & HR & $15.0 \mathrm{c}$ & 1.7 & MR & $42.5 \mathrm{~b}$ \\
\hline 'Auraprince' & $\mathrm{CH}$ & 0.7 & HR & $17.5 \mathrm{c}$ & 2.8 & SU & $70.0 \mathrm{a}$ \\
\hline 'Magisto' & $\mathrm{CA}$ & 0.8 & HR & $20.0 \mathrm{~b}$ & 3.0 & SU & $75.0 \mathrm{a}$ \\
\hline 'Guaporé' & GA & 0.8 & HR & $20.0 \mathrm{~b}$ & 1.8 & MR & $45.0 \mathrm{~b}$ \\
\hline 'Mabel' & PS & 0.8 & HR & $20.0 \mathrm{~b}$ & 1.1 & MR & $27.5 \mathrm{~b}$ \\
\hline 'AF 646' & YT & 1.0 & HR & $25.0 \mathrm{~b}$ & 2.8 & SU & $70.0 \mathrm{a}$ \\
\hline 'Néctar’ & GA & 1.0 & HR & $25.0 \mathrm{~b}$ & 3.0 & SU & $75.0 \mathrm{a}$ \\
\hline 'DRG 2278' & GA & 1.0 & HR & $25.0 \mathrm{~b}$ & 1.6 & MR & $40.0 \mathrm{~b}$ \\
\hline ' 8530 ' & GA & 1.0 & HR & $25.0 \mathrm{~b}$ & 2.3 & SU & $57.5 \mathrm{~b}$ \\
\hline 'RZ 34146' & YT & 1.1 & MR & $27.5 \mathrm{~b}$ & 1.8 & MR & $45.0 \mathrm{~b}$ \\
\hline 'Acclaim' & $\mathrm{CA}$ & 1.1 & MR & $27.5 \mathrm{~b}$ & 2.9 & $\mathrm{SU}$ & $72.5 \mathrm{a}$ \\
\hline 'Solarnet' & GA & 1.1 & MR & $27.5 \mathrm{~b}$ & 2.0 & MR & $50.0 \mathrm{~b}$ \\
\hline 'Torreon' & $\mathrm{CA}$ & 1.2 & MR & $30.0 \mathrm{~b}$ & 1.8 & MR & $45.0 \mathrm{~b}$ \\
\hline 'Galileo' & GA & 1.3 & MR & $32.5 \mathrm{a}$ & 2.1 & SU & $52.5 \mathrm{~b}$ \\
\hline 'Caribbean Gold' & HA & 1.3 & MR & $32.5 \mathrm{a}$ & 1.6 & MR & $40.0 \mathrm{~b}$ \\
\hline 'RZ 34794’ & HA & 1.3 & MR & $32.5 \mathrm{a}$ & 1.4 & MR & $35.0 \mathrm{~b}$ \\
\hline 'Mandacaru' & YT & 1.4 & MR & $35.0 \mathrm{a}$ & 2.9 & SU & $72.5 \mathrm{a}$ \\
\hline ‘Gladial' & YT & 1.4 & MR & $35.0 \mathrm{a}$ & 1.4 & MR & $35.0 \mathrm{~b}$ \\
\hline 'PS 4048' & $\mathrm{CA}$ & 1.4 & MR & $35.0 \mathrm{a}$ & 2.1 & SU & $52.5 \mathrm{~b}$ \\
\hline 'PS 4045' & $\mathrm{CA}$ & 1.4 & MR & $35.0 \mathrm{a}$ & 2.3 & SU & $57.5 \mathrm{~b}$ \\
\hline 'Magrite' & $\mathrm{CA}$ & 1.4 & MR & $35.0 \mathrm{a}$ & 2.4 & SU & $60.0 \mathrm{a}$ \\
\hline
\end{tabular}

${ }^{1}$ Commercial type: $\mathrm{YT}=$ Yellow; $\mathrm{CA}=$ Cantaloupe; $\mathrm{CH}=$ Charantais; $\mathrm{GA}=$ Gália; $\mathrm{HA}=$ Harper; $\mathrm{HD}=$ Honeydew; $\mathrm{PS}=$ Piel de Sapo; ${ }^{2}$ Disease reaction class according to diagrammatic scale of 0 (healthy roots without lesions or discolourations) to 4 (severe maceration), adapted by Bruton et al. $(2000) ;{ }^{3}$ Disease reaction: $0=$ similar to immune (SI); $0.1-1.0=$ highly resistant (HR); 1.1-2.0 = moderately resistant (MR); $2.1-3.0=$ susceptible $(\mathrm{SU}) ; 3.1-4.0=$ highly susceptible (HS); ${ }^{4}$ The severity of the disease, calculated by the McKinney index (1923), using the frequency of disease classes considering a scale of grades from 0 to $4 ;{ }^{5} \mathrm{Media}$ of four repetitions. Means followed by the same letter in the column did not differ significantly from each other by the Scott-Knott test, $\mathrm{P}=0.05$ ). 
Table 1. Continued.

\begin{tabular}{|c|c|c|c|c|c|c|c|}
\hline \multirow[t]{3}{*}{ Genotypes } & \multirow{3}{*}{$\begin{array}{c}\text { Commercial } \\
\text { type }^{1}\end{array}$} & \multicolumn{3}{|c|}{ 1st Cycle (dry period) } & \multicolumn{3}{|c|}{ 2nd Cycle (wet period) } \\
\hline & & \multicolumn{2}{|c|}{ Class of disease } & \multirow{2}{*}{$\begin{array}{l}\text { Severity } \\
(\%)^{4}\end{array}$} & \multicolumn{2}{|c|}{ Class of disease } & \multirow{2}{*}{$\begin{array}{c}\text { Severity } \\
(\%)\end{array}$} \\
\hline & & Mean $^{2}$ & Reaction $^{3}$ & & Mean & Reaction & \\
\hline 'Galon 47' & $\overline{G A}$ & 1.5 & $\mathrm{MR}$ & $37.5 \mathrm{a}$ & 1.4 & $\mathrm{MR}$ & $35.0 \mathrm{~b}$ \\
\hline 'Num 8538' & GA & 1.5 & MR & $37.5 \mathrm{a}$ & 2.2 & SU & $55.0 \mathrm{~b}$ \\
\hline 'Filipo' & PS & 1.5 & MR & $37.5 \mathrm{a}$ & 2.4 & SU & $60.0 \mathrm{a}$ \\
\hline 'Gold Star' & YT & 1.6 & MR & $40.0 \mathrm{a}$ & 1.7 & MR & $42.5 \mathrm{~b}$ \\
\hline 'Coronado' & CA & 1.6 & MR & $40.0 \mathrm{a}$ & 1.9 & MR & $47.5 \mathrm{~b}$ \\
\hline '07X8081' & $\mathrm{HA}$ & 1.6 & MR & $40.0 \mathrm{a}$ & 1.5 & MR & $37.5 \mathrm{~b}$ \\
\hline 'Orange Flesh' & HD & 1.6 & MR & $40.0 \mathrm{a}$ & 3.6 & HS & $90.0 \mathrm{a}$ \\
\hline 'Medellín' & PS & 1.6 & MR & $40.0 \mathrm{a}$ & 2.9 & SU & $72.5 \mathrm{a}$ \\
\hline 'Sancho' & PS & 1.6 & MR & $40.0 \mathrm{a}$ & 2.4 & SU & $60.0 \mathrm{a}$ \\
\hline 'Hybrix' & YT & 1.7 & MR & $42.5 \mathrm{a}$ & 3.5 & HS & $87.5 \mathrm{a}$ \\
\hline 'Hy-Mark' & CA & 1.7 & MR & $42.5 \mathrm{a}$ & 1.6 & MR & $40.0 \mathrm{~b}$ \\
\hline 'Canarion' & YT & 1.8 & MR & $45.0 \mathrm{a}$ & 2.9 & SU & $72.5 \mathrm{a}$ \\
\hline 'Gold Pride' & YT & 1.8 & MR & $45.0 \mathrm{a}$ & 2.4 & SU & $60.0 \mathrm{a}$ \\
\hline 'RML 0031' & CA & 1.8 & MR & $45.0 \mathrm{a}$ & 2.9 & SU & $72.5 \mathrm{a}$ \\
\hline ‘Cyro’' & GA & 1.8 & MR & $45.0 \mathrm{a}$ & 2.6 & SU & $65.0 \mathrm{a}$ \\
\hline 'DRY 9150’ & YT & 1.9 & MR & $47.5 \mathrm{a}$ & 2.4 & SU & $60.0 \mathrm{a}$ \\
\hline 'Goldex' & YT & 1.9 & MR & $47.5 \mathrm{a}$ & 3.7 & HS & $92.5 \mathrm{a}$ \\
\hline 'PS 1001' & YT & 1.9 & MR & $47.5 \mathrm{a}$ & 2.2 & SU & $55.0 \mathrm{~b}$ \\
\hline ‘ $10 / 00 ’$ & YT & 2.1 & SU & $52.5 \mathrm{a}$ & 3.7 & HS & $92.5 \mathrm{a}$ \\
\hline 'Natal' & YT & 2.4 & SU & $60.0 \mathrm{a}$ & 2.4 & SU & $60.0 \mathrm{a}$ \\
\hline CVs (\%) & & & & 14.8 & & & 15.3 \\
\hline
\end{tabular}

${ }^{1}$ Commercial type: $\mathrm{YT}=$ Yellow; $\mathrm{CA}=$ Cantaloupe $\mathrm{CH}=$ Charantais; $\mathrm{GA}=$ Gália; $\mathrm{HA}=$ Harper; HD = Honeydew; $\mathrm{PS}=$ Piel de Sapo; ${ }^{2}$ Disease reaction class according to diagrammatic scale of 0 (healthy roots without lesions or discolourations) to 4 (severe maceration), adapted by Bruton et al. $(2000) ;{ }^{3}$ Disease reaction: $0=$ similar to immune (SI); $0.1-1.0=$ highly resistant (HR); 1.1-2.0 = moderately resistant (MR); $2.1-3.0=$ susceptible $(\mathrm{SU}) ; 3.1-4.0=$ highly susceptible (HS); ${ }^{4}$ The severity of the disease, calculated by the McKinney index (1923), using the frequency of disease classes considering a scale of grades from 0 to $4 ;{ }^{5} \mathrm{Media}$ of four repetitions. Means followed by the same letter in the column did not differ significantly from each other by the Scott-Knott test, $\mathrm{P}=0.05$ ).

The results demonstrate the difficulty in obtaining sources with high levels of resistance to MRRVD, probably due to the high aggressiveness of the pathogen (MARTYN; MILLER, 1996; COHEN et al., 2012). In the first crop cycle, $28.9 \%$ of the tested genotypes presented a high resistance reaction to MRRVD ('RZ 34292', 'RZ 34130', 'Massaï', 'Estoril', 'Kousto', 'Auraprince', 'Magisto', 'Guaporé', 'Mabel', 'AF 646', 'Néctar', 'DRG 2278', ' 8530 '), $66.7 \%$ behaved as moderately resistant ('RZ 34146', 'Acclaim', 'Solarnet', 'Torreon', 'Galileo', 'Caribbean Gold', 'RZ 34794', 'Mandacaru', 'Gladial', 'PS 4048', 'PS 4045', 'Magrite', 'Galon 47', 'Num 8538', 'Filipo', 'Gold Star', 'Coronado', '07X8081', 'Orange Flesh', 'Medellín', 'Sancho', 'Hybrix', 'Hy-Mark', 'Canarion', 'Gold Pride', 'RML 0031', 'Cyro', 'DRY 9150', 'Goldex', 'PS 1001'), while 4.4\% behaved as susceptible ('10/00' e 'Natal'). None of the genotypes behaved as highly susceptible. On the other hand, in the second cropping season no genotype showed a high resistance reaction, while $42.2 \%$ showed moderate resistance ('RZ 34292', 'RZ 34130', 'Massaï', 'Estoril', 'Kousto', 'Guaporé', 'Mabel', 'DRG 2278', 'RZ 34146', 'Solarnet', 'Torreon', 'Caribbean Gold', 'RZ 34794', 'Gladial', 'Galon 47', 'Gold Star', 'Coronado', '07X8081', 'Hy-Mark'), $48.9 \%$ as susceptible ('Auraprince', 'Magisto', 'AF 646', 'Néctar', '8530', 'Acclaim', 'Galileo', 'Mandacaru', 'PS 4048', 'PS 4045', 'Magrite', 'Num 8538', 'Filipo', 'Medellín', 'Sancho', 'Canarion', 'Gold Pride', 'RML 0031', 'Cyro', 'DRY 9150', 'PS 1001 ', 'Natal') and $8.9 \%$ as highly susceptible ('Goldex', 'Hybrix', 'Orange Flesh' e '10/00') (Table 1 and Figure 1). 


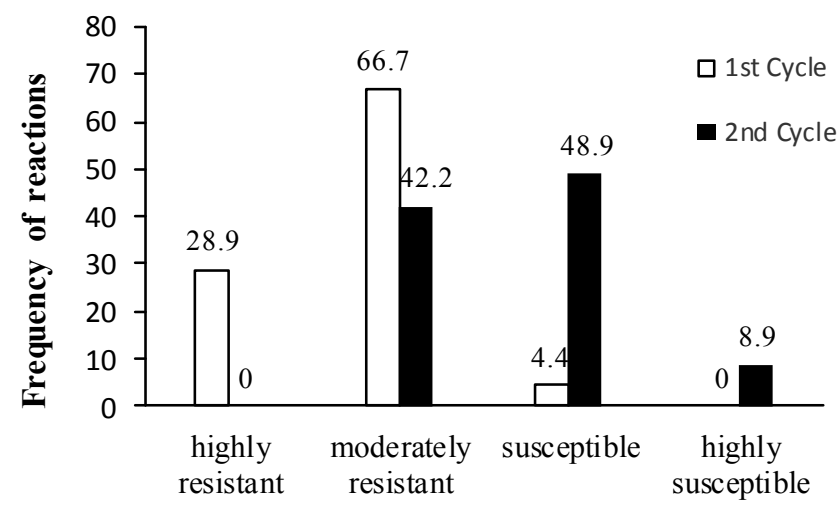

\section{Reaction class}

Figure 1. Frequency of reaction classes of 45 melon genotypes to Monosporascus cannonballus in two crop cycles, under greenhouse conditions.

Pathogenicity studies for M. cannonballus have been previously carried out in different countries, but no resistant or tolerant genotype was found for melon. However, the variation in the degree of resistance found among the genotypes in the present research, corroborates with the literature (WOLFF, 1995; MARTYN; MILLER, 1996; SALES et al., 2002; ANDRADE et al., 2005; EDELSTEIN et al., 2017).

It is important to note that different internal and external plant factors perform important functions in the development of epidemics, among which, the genetic resistance levels or host susceptibility, stand out. In addition, diseases caused by soil-borne pathogens are predominantly influenced by climate (MIYASAKA, 2008).

Overall, the genotypes 'DRG 2278', 'Estoril', 'Guaporé', 'Kousto', 'Mabel', 'Massaï', 'RZ 34130' and 'RZ 34292' were identified as highly resistant and moderately resistant in the first and second cropping seasons, respectively. These genotypes can be classified as promising sources of resistance to $M$. cannonballus and should be preferred in commercial fields where the soil is infested with the pathogen.

Severity levels ranged from 7.5 to $60 \%$ and 27.5 to $92.5 \%$ for the first and second cropping seasons, respectively, with corresponding mean ascospore $\mathrm{g}^{-1}$ soil densities of 3.6 and 1.0. These data can be explained by the increase in the reproductive capacity of $M$. cannonballus in successive melon cultivation when the production of ascospores occurs in the perithecia at the end of the previous cycle, serving as a primary survival structure and source of inoculum for new infections. In addition, the reduction in ascospore density in the second cycle may be due to their germination in the plant rhizosphere and the infected root, which occurs when stimulated by root exudates and soil microorganisms (STANGHELLINI; KIM; WAUGH, 2000).

Nevertheless, the results show a certain contradiction to other studies, in which the highest rates of the disease were found during the hottest periods of the year, as the speed and severity of the disease are associated with high temperatures (PIVONIA et al., 2002), the highest germination rate of ascospores occurs at $35{ }^{\circ} \mathrm{C}$ (STANGHELLINI; KIM; WAUGH, 2000) and these periods cause increased activity of thermotolerant microorganisms (PIVONIA et al., 2002). It is worth mentioning that in the rainy season, root infection occurs later than in the hot season (STANGHELLINI et al., 2004). Moreover, the data show that the presence of $M$. cannonballus alone is insufficient for disease development since several biotic or abiotic factors must be considered (STANGHELLINI; MATHEWS; MISAGHI, 2010). Besides, elevated temperatures are not the main factor influencing disease severity.

By Scott-Knott's cluster analysis, five groups of melon genotypes were distinguished for $M$. cannonballus-induced levels of MRRVD severity (Table 1). The genotypes 'Auraprince', 'Estoril', 'Kousto', 'Massaï', 'RZ 34130' and 'RZ 34292' showed the lowest levels of severity during the first crop cycle, differing significantly $(\mathrm{P}<0.05)$ from the other genotypes. Although the genotypes 'AF 464', 'DRG 2278', 'Guaporé', 'Mabel', 'Magisto', 'Nectar' and '8530' also behaved as highly resistant (Table 1), the severity of MRRVD in these genotypes did not differ significantly $(\mathrm{P}<0.05)$ from those that were moderately resistant ('Acclain', 'RZ 34146', 'Solarnet', 'Torreon'). Furthermore, the '10/00 ' and 'Natal' genotypes, identified as susceptible, did not differ $(\mathrm{P}<0.05)$ from the other genotypes that behaved as moderately resistant (Table 1). However, in the second cycle of cultivation, the highest severity of the disease was observed in 'Goldex', 'Hybrix', 'Orange Flesh' and '10/00', with 92.5, 87.5, 90.0 and $92.5 \%$, respectively. Although they did not differ $(\mathrm{P}<0.05)$ from most of the susceptible varieties, they differed from those that were moderately resistant (Table 1).

We should note that in the present study, in both summer and winter conditions, when cultivating plants in small pots, it was not possible to 
obtain fruits, yet the fresh weight of the shoot should not be considered as a good indicator of the disease in melon grown in a greenhouse. Instead, the root damage index is a precise parameter to explain the effects of fungi on plants less than 60 days old (BELTRÁN et al., 2005).

It is important to report that little quantitative information exists on the development of MRRVD under field conditions. Such knowledge is valuable for the understanding of the disease epidemiology and would be a useful instrument for the implementation of management strategies.

As for other diseases, the most practical and economical method to manage MRRVD efficiently would be through the use of resistant varieties. However, no genotype was highly resistant to this disease in the two cropping seasons studied, even though median resistance was reported under both growth conditions. It is necessary to emphasise that the use of resistance alone is not sufficient for adequate management of root diseases. It is essential to adopt complementary strategies to maximise the durability of resistance to M. cannonballus, such as the use of grafting, rotation of cultivated areas, crops and melon genotypes, as well as avoiding injury to plants during cultural practices, and to destroy any crop residue remaining in the field.

\section{CONCLUSIONS}

The genotypes 'DRG 2278', 'Estoril', 'Guaporé', 'Kousto', 'Mabel', 'Massaï', 'RZ 34130' and 'RZ 34292 were identified as highly resistant and moderately resistant in the first and second cropping seasons, respectively. These genotypes are promising sources of resistance to MRRVD, and should, therefore, be preferred in commercial melon fields infested with $M$. cannonballus.

\section{ACKNOWLEDGEMENTS}

Special thanks to the Conselho Nacional de Desenvolvimento Científico e Tecnológico (CNPq), for the financial support to this research.

\section{REFERENCES}

ALEANDRI, M. P. et al. Effects of preconditioning through mycorrhizal inoculation on the control of melon root rot and vine decline caused by Monosporascus cannonballus. Journal of Phytopathology, v. 163, n. 11-12, p. 898-907, 2015.

AL-MAWAALI, Q. S. et al. Etiology, development and reaction of muskmelon to vine decline under arid conditions of Oman. Phytopathologia
Mediterranea, v. 52, n. 3, p. 457-465, 2013.

AL-MAWAALI, Q. S. et al. Effect of rootstock on muskmelon cultivar reaction to vine decline disease and yield under arid conditions. Journal of Agricultural and Marine Sciences, v. 21, n. 1, p. 47-56, 2016.

ALVARES, C. A. et al. Köppen's climate classification map for Brazil. Meteorologische Zeitschrift, v. 22, n. 6, p. 711-728, 2014.

ANDRADE, D. E. G. T. et al. Frequência de fungos associados ao colapso do meloeiro e relação com características físicas, químicas e microbiológicas dos solos. Summa Phytopathologica, v. 31, n. 4, p. 327-333, 2005

ANTONELLI, M. G. et al. Plant growth-promoting bacteria from solarized soil with the ability to protect melon against root rot and vine decline caused by Monosporascus cannonballus. Journal of Phytopathology, v. 161, n. 7-8, p. 485-496, 2013.

AWAD, H. M. Evaluation of plant extracts and essential oils for the control of sudden wilt disease of watermelon plants. International Journal of Current Microbiology and Applied Sciences, v. 5, n. 5 , p. 949-962, 2016.

BELTRÁN, R. et al. Population dynamics of Monosporascus cannonballus ascospores in marsh soils in eastern Spain. European Journal of Plant Pathology, v. 113, n. 4, p. 357-365, 2005.

BRUTON, B. D. et al. Assessment of virulence of Acremonium cucurbitacearum and Monosporascus cannonballus on Cucumis melo. Plant Disease, v. 84, n. 8, p. 907-913, 2000.

COHEN, R. et al. Advances in the biology and management of monosporascus vine decline and wilt of melons and other cucurbits. Horticultural Reviews, v. 39, n. 1, p. 77-120, 2012.

EDELSTEIN, M. et al. Performance of interspecific Cucurbita rootstocks compared to their parental lines. Scientia Horticulturae, v. 216, n. 1, p. 45-50, 2017.

FERNANDES, L. C. B. et al. Fungitoxicidade dos extratos vegetais e do óleo essencial de Lippia gracilis Schauer sobre o fungo Monosporascus cannonballus Pollack e Uecker. Summa Phytopathologica, v. 41, n. 2, p. 153-155, 2015.

FITA, A. et al. 'Piel de Sapo' breeding lines tolerant to melon vine decline. HortScience, v. 44, n. 5, p. 1458-1460, 2009. 
INSTITUTO BRASILEIRO DE GEOGRAFIA E ESTATÍSTICA - IBGE. SIDRA - Sistema IBGE de Recuperação Automática. Rio de Janeiro, 2018. Disponível em: <https://sidra.ibge.gov.br/ tabela/5457>. Acesso em: 03 dec. 2018.

IGLESIAS, A.; PICÓ, B.; NUEZ, F. Pathogenicity of fungi associated with melon vine decline and selection strategies for breeding resistant cultivars. Annals of Applied Biology, v. 137, n. 2, p. 141-151, 2000 .

MARKAKIS, E. A. et al. First report of root rot and vine decline of melon caused by Monosporascus cannonballus in Greece. Plant Disease, v. 102, n. 5, p. 1036, 2018.

MARTYN, R. D.; MILLER, M. E. Monosporascus root rot and vine decline: an emerging disease of melon worldwide. Plant Disease, v. 80, n. 7, p. 716$725,1996$.

MCKINNEY, H. H. Influence of soil temperature and moisture on infection of wheat seedlings by Helminthosporium sativum. Journal of Agricultural Research, v. 26, n. 5, p. 195-217, 1923.

MEDEIROS, E. V. et al. Influência do agrotêxtil sobre a densidade populacional de Monosporascus cannonballus em solos cultivados com melancia (Citrullus lanatus). Ciência e Agrotecnologia, v. 32, n. 3, p. 797-803, 2008.

MIYASAKA S. Manejo da biomassa e do solo visando à sustentabilidade da agricultura brasileira. 1. ed. São Paulo, SP: Navegar, 2008. 192 p.

PIVONIA, S. et al. Effect of soil temperature on disease development in melon plants infected by Monosporascus cannonballus. Plant Pathology, v. 51, n. 4, p. 472-479, 2002.

PIVONIA, S. et al. Management of Monosporascus sudden wilt of melon by soil application of fungicides. European Journal of Plant Pathology, v. 128, n. 2, p. 201-209, 2010.

RADEWALD, K. C.; FERRIN, D. M.; STANGHELLINI, M. E. Sanitation practices that inhibit reproduction of Monosporascus cannonballus in melon roots left in the field after crop termination. Plant Pathology, v. 53, n. 5, p. 660-668, 2004.

SALES JÚNIOR, R. et al. Análisis de distintos tipos de azúcares en el método de extracción de ascosporas de Monosporascus cannonballus en suelo. Fitopatologia Brasileira, v. 31, n. 2, p. 185 -
$187,2006$.

SALES JÚNIOR, R. et al. Comportamento de cultivares de meloeiro e melancia inoculados com Acremonium cucurbitacearum e Monosporascus cannonballus. Fitopatologia Brasileira, v. 27, n. 2, p. 206-210, 2002.

SALES JÚNIOR, R. et al. First Report of Monosporascus cannonballus on Watermelon in Brazil. Plant Disease, v. 94, n. 2, p. 278, 2010.

SALES JÚNIOR, R. et al. Influência da adubação verde no declínio de monosporascus em solo naturalmente infestado. Horticultura Brasileira, v. 35, n. 1, p. 135-140, 2017.

STANGHELLINI, M. E.; KIM, D. H.; WAUGH, M. M. Microbe-mediated germination of ascospores of Monosporascus cannonballus. Phytopathology, v. 90, n. 3, p. 243-247, 2000.

STANGHELLINI, M. E. et al. Crop residues destruction strategies that enhance rather than inhibit reproduction of Monosporascus cannonballus. Plant Pathology, v. 53, n. 1, p. 50-53, 2004.

STANGHELLINI, M. E.; MATHEWS, D. M.; MISAGHI, I. J. Pathogenicity and management of Olpidium bornovanus, a root pathogen of melons. Plant Disease, v. 94, n. 2, p. 163-166, 2010.

WOLFF, D. W. Evaluation of melon germplasm for resistance to Monosporascus root rot/vine decline symptom expression in melon (Cucumis melo L.). In: PROCEEDINGS, EUCARPIA MEETING ON CUCURBIT GENETICS AND BREEDING, 6. Anais... Málaga, 1995. p. 224-228. 1995.

YAN, L. Y. et al. First report of root rot and vine decline of melon caused by Monosporascus cannonballus in Eastern Mainland China. Plant Disease, v. 100, n. 3, p. 651, 2016. 